\title{
A STUDY OF NONBANKING FINANCIAL COMPANIES IN INDIA
}

Rajeswari Sengupta, Lei Lei Song, and Harsh Vardhan

NO. 83

October 2021

\section{ADB SOUTH ASIA WORKING PAPER SERIES}

$\mathrm{ADB}$ 


\section{ADB South Asia Working Paper Series}

\section{A Study of Nonbanking Financial Companies in India}

Rajeswari Sengupta, Lei Lei Song, and Harsh Vardhan

No. 83 | October 2021
Rajeswari Sengupta is an assistant professor of economics at Indira Gandhi Institute of Development Research, Mumbai. Lei Lei Song is director of Economic Analysis and Operational Support Division, Economic Research and Regional Cooperation Department at the Asian Development Bank. Harsh Vardhan is executive-in-residence at the Centre for Financial Studies, SP Jain Institute of Management \& Research.

The authors gratefully acknowledge the helpful comments and feedback received from Reza Vaez-Zadeh on an earlier version of the paper. The authors also thank Shalini Mittal for helpful feedback and research assistance. Comments by Madhavi Pundit and Utsav Kumar helped improved the paper. 
(C) 2021 Asian Development Bank

6 ADB Avenue, Mandaluyong City, 1550 Metro Manila, Philippines

Tel +632 8632 4444; Fax +63286362444

www.adb.org

Some rights reserved. Published in 2021.

Printed in the Philippines

ISSN 2313-5867 (print), 2313-5875 (electronic)

Publication Stock No. WPS210381-2

DOI: http://dx.doi.org/10.22617/WPS210381-2

The views expressed in this publication are those of the authors and do not necessarily reflect the views and policies of the Asian Development Bank (ADB) or its Board of Governors or the governments they represent.

ADB does not guarantee the accuracy of the data included in this publication and accepts no responsibility for any consequence of their use. The mention of specific companies or products of manufacturers does not imply that they are endorsed or recommended by ADB in preference to others of a similar nature that are not mentioned.

By making any designation of or reference to a particular territory or geographic area, or by using the term "country" in this document, $A D B$ does not intend to make any judgments as to the legal or other status of any territory or area.

This work is available under the Creative Commons Attribution 3.0 IGO license (CC BY 3.0 IGO) https://creativecommons.org/licenses/by/3.0/igo/. By using the content of this publication, you agree to be bound by the terms of this license. For attribution, translations, adaptations, and permissions, please read the provisions and terms of use at https://www.adb.org/terms-use\#openaccess.

This CC license does not apply to non-ADB copyright materials in this publication. If the material is attributed to another source, please contact the copyright owner or publisher of that source for permission to reproduce it. ADB cannot be held liable for any claims that arise as a result of your use of the material.

Please contact pubsmarketing@adb.org if you have questions or comments with respect to content, or if you wish to obtain copyright permission for your intended use that does not fall within these terms, or for permission to use the ADB logo.

The ADB South Asia Working Paper Series is a forum for ongoing and recently completed research and policy studies undertaken in $A D B$ or on its behalf. It is meant to enhance greater understanding of current important economic and development issues in South Asia, promote policy dialogue among stakeholders, and facilitate reforms and development management.

The ADB South Asia Working Paper Series is a quick-disseminating, informal publication whose titles could subsequently be revised for publication as articles in professional journals or chapters in books. The series is maintained by the South Asia Department. The series will be made available on the ADB website and on hard copy.

Corrigenda to ADB publications may be found at http://www.adb.org/publications/corrigenda.

Notes:

In this publication, “\$” refers to United States dollars and “₹” refers to Indian rupees. 


\section{CONTENTS}

FIGURES

ABSTRACT V v

ABBREVIATIONS vi

$\begin{array}{ll}\text { I. INTRODUCTION } & 1\end{array}$

II. COMPARISON OF NONBANKING FINANCIAL COMPANIES 4 WITH COMMERCIAL BANKS

III. RISE OF NONBANKING FINANCIAL COMPANIES IN THE 2010s 6

IV. GENESIS AND ANATOMY OF THE NONBANKING FINANCIAL COMPANY 11 CRISIS OF 2018

$\begin{array}{ll}\text { V. HOUSING FINANCE COMPANIES } & 14\end{array}$

VI. REGULATORY RESPONSE TO THE NONBANKING FINANCIAL COMPANY CRISIS 15

$\begin{array}{ll}\text { VII. IMPACT OF THE COVID-19 PANDEMIC } & 16\end{array}$

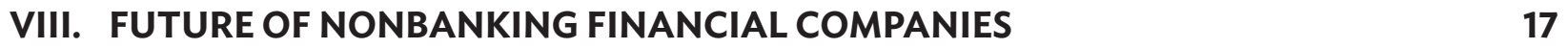

$\begin{array}{lr}\text { REFERENCES } & 20\end{array}$ 


\section{FIGURES}

1 Flow of Incremental Commercial Credit in India from Various Sources 2

2 Growth of Incremental Commercial Credit Flows from Various Sources 4

3 Gross Nonperforming Assets in the Indian Banking Sector and 7 Nonbanking Financial Companies

4 Share of Different Types of Banks in Incremental Credit Flows

5 Growth of Bank Credit across Key Sectors 8

6 Assets under Management by Mutual Funds 9

7 Sector Deployment of Nonbanking Financial Company Credit 10

8 Incremental Funding of Nonbanking Financial Companies 10

9 Nonbanking Financial Company and Housing Finance Company credit spreads 12

10 Public Issuances of Nonconvertible Debentures by Nonbanking Financial Companies 13

11 Bank Lending to Nonbanking Financial Companies and Housing Finance Companies 14 


\begin{abstract}
In late 2018, the default by a major nonbanking financial company (NBFC) in India led to a credit crunch in the Indian economy. The crisis raises questions about the business model of NBFCs in India, and the role they play alongside banks in the economy. This paper analyzes the evolution of the NBFC sector in India over time and its importance in extending credit, and it discusses the factors that may have contributed to the 2018 crisis. The paper attempts to understand the advantages and disadvantages of the business model of NBFCs, and the drivers of their rapid rise and subsequent challenges. The paper also briefly discusses the potential impact of the coronavirus pandemic on the NBFC sector. Drawing on lessons from the past, NBFCs need to be strengthened to play an important role in India's financial landscape.
\end{abstract}

Keywords: Nonbanking financial company, financial intermediation, financial regulation, systemic risk, liquidity crunch 


\section{ABBREVIATIONS}

$\begin{array}{lll}\text { CAGR } & - & \text { compound annual growth rate } \\ \text { COVID-19 } & - & \text { coronavirus disease } \\ \text { FY } & - & \text { fiscal year } \\ \text { IL\&FS } & - & \text { Infrastructure Leasing \& Financial Services Limited } \\ \text { NBFC } & - & \text { nonbanking financial company } \\ \text { NPA } & - & \text { nonperforming asset } \\ \text { RBI } & - & \text { Reserve Bank of India }\end{array}$




\section{INTRODUCTION}

1. A major driver of growth in an emerging economy such as India is sustained investment by the private sector. For triggering as well as sustaining investments, a critical factor is stable availability of credit. Historically in the Indian economy, credit has grown faster than gross domestic product (GDP). The ratio between the growth of bank credit and the growth of nominal GDP ranged from 1 to 2 and averaged 1.42 from 1962 to 2019. For most of this period, banks constituted the predominant source of credit in the formal economy whereas bond markets and nonbank lenders accounted for a relatively smaller share of credit.

2. Since 2014, credit growth in the banking sector has been lackluster largely because of burgeoning nonperforming assets (NPAs) on the balance sheets of banks, especially public sector banks (PSBs). Some part of the shortfall in credit from the banking sector was compensated by flows of credit from nonbanking financial companies (NBFCs) until 2018. In September 2018, Infrastructure Leasing \& Financial Services Limited (IL\&FS), a prominent NBFC, defaulted on its debt obligations. This event precipitated a crisis that engulfed the entire NBFC sector. Consequently, in the first half of fiscal year 2020 (FY2020, ended in March 2020), there was a sharp decline in incremental credit from both commercial banks and NBFCs.

3. Even as the NBFC sector was struggling to recover from the 2018 crisis, the country was hit by another massive shock in the form of the coronavirus (COVID-19) pandemic, which began spreading rapidly in India from March 2020. In response to the outbreak of the highly contagious disease, the Government of India announced a nationwide lockdown from 25 March 2020, which continued until June 2020. During this period, most economic activity came to an abrupt halt, nonessential businesses were suspended, and essential businesses got heavily curtailed. This shock has had an adverse impact on the NBFC sector in terms of constrained availability of funding as well as growth in NPAs.

4. While much has been written about the NPA problems of the Indian banking sector after 2008 (e.g., Sengupta and Vardhan 2017 and 2019b), less work has been done to study the NBFC sector and document the structural issues that this sector faces in light of the 2018 crisis as well as the ongoing pandemic-related crisis.

5. The objectives of this paper are to (i) analyze the evolution of the NBFC sector in India in the past two decades, particularly in the context of its role in commercial credit; (ii) understand the 2018 crisis episode; (iii) briefly discuss the potential impact of the COVID-19 pandemic on this sector; and (iv) draw lessons from these events to evaluate the future of NBFCs. The paper attempts to understand the advantages and disadvantages of the business model of NBFCs, and the drivers of their rapid rise and subsequent challenges.

6. There are typically two models of providing credit: (i) intermediated credit that flows through the balance sheet of financial institutions such as banks and NBFCs, and (ii) market credit that flows through the bond market (sometimes through risk pass-through vehicles such as mutual funds). Historically, commercial credit in India has primarily relied on financial institutions because bond markets have not had the necessary liquidity and depth.

7. Within financial institutions, commercial banks have been the predominant providers of credit to the corporate sector as well as to consumers. Commercial banks, by virtue of their ability to accept deposits, have always been the largest and the most developed platform for converting household savings into investmentsthe quintessential role of financial intermediaries. In the past decade or so, however, growth in bank credit has been slowing down and the nonbank sources of credit, especially NBFCs and housing finance companies (HFCs), have gathered momentum as alternative institutions for providing credit (Figure 1). 
Figure 1: Flow of Incremental Commercial Credit in India from Various Sources

(₹ trillion)

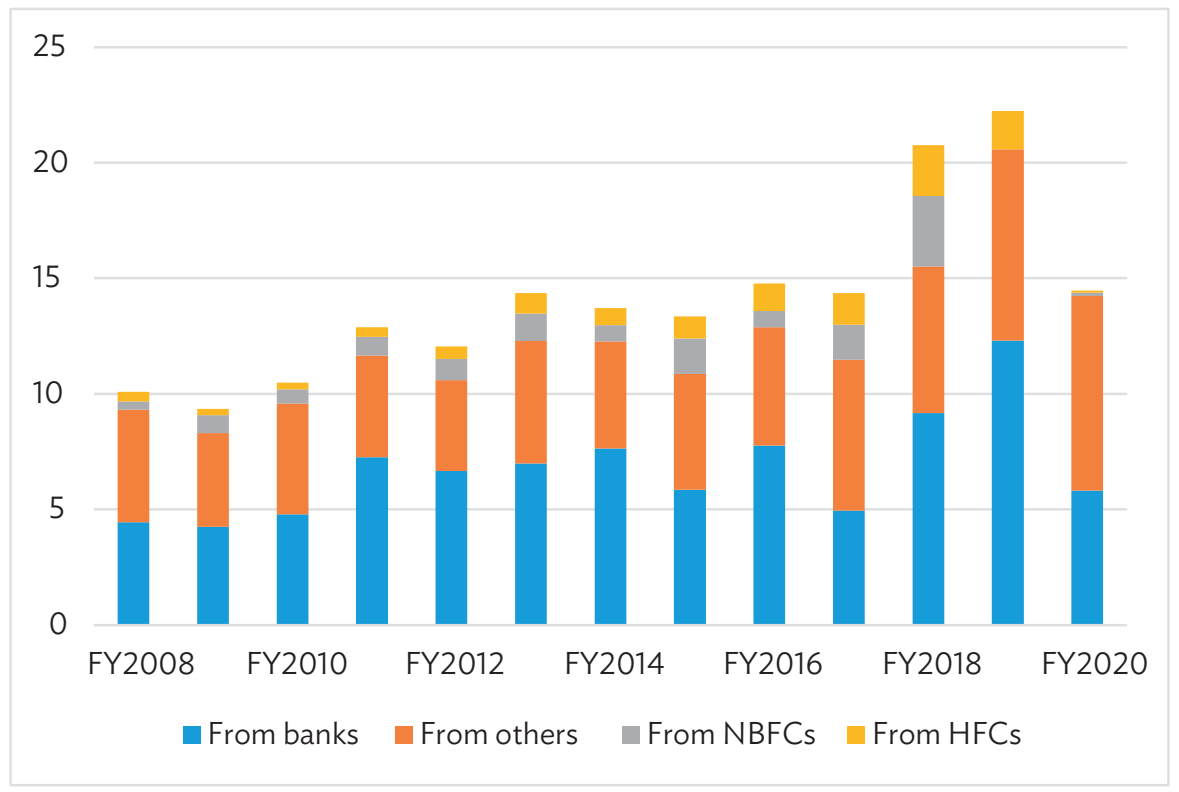

FY = fiscal year, $\mathrm{HFC}=$ housing finance company, NBFC = nonbanking financial company.

Notes:

1. Fiscal years, from 1 April of the previous year to 31 March of the year.

2. "Others" includes bond issuance to insurance companies, mutual funds, commercial paper issuance, and external commercial borrowings.

Source: Reserve Bank of India. 2020. Handbook of Statistics on the Indian Economy, 2019-20. Mumbai.

8. NBFCs, as their name suggests, are nonbanks that provide credit like banks. A crucial difference between banks and NBFCs arises in their funding model. While all banks are permitted to accept public deposits - both demand and time deposits - no NBFC is permitted to accept demand deposits and most of them are not permitted to accept time deposits. Only a small fraction of NBFCs are permitted to accept time deposits from the public, and no new license has been issued to deposit-taking NBFCs (NBFCs-D) since 1997. As a result, public deposits constitute a tiny portion of the overall liabilities of NBFCs. Most NBFCs fund themselves by borrowing from commercial banks and by issuing bonds or debentures (often to banks and mutual funds), in addition to equity capital.

9. NBFCs differ widely in the business (lending) activities they engage in, their geographic and customer focus, and their size. The Reserve Bank of India (RBI), the central bank and the regulator for banks as well as NBFCs, uses three parameters to classify NBFCs:

(i) Nature of business activities. Based on the business of the company, 10 different types of NBFCs have been defined. Of these, three are important from the point of view of providing credit: investment and credit companies, HFCs, and microfinance institutions. Microfinance institutions primarily provide microloans to borrowers (mostly women) from economically weaker segments under joint liability group lending programs. Hence,

\footnotetext{
NBFCs were set up under the Companies Act, 1956 and used to accept deposits. Given the dramatic increase in the number and volume of deposits received by NBFCs-D, in 1997 a comprehensive legislative framework was introduced to protect the interest of the depositors. Since then, the Reserve Bank of India (RBI) has actively discouraged the acceptance of deposits by NBFCs and accordingly stopped giving new licenses to NBFCs-D.
} 
they are not relevant for understanding commercial credit, whereas credit and investment companies (referred to most commonly by the generic name NBFCs) and HFCs are important in the domain of commercial credit.

Until July 2019, HFCs were regulated and supervised by the National Housing Bank (NHB). Since August 2019, the regulation of HFCs has been moved to the RBI while their supervision remains with the NHB. The total HFC loan book was about ₹20 trillion as of 19 March 2020 - a significant part of the overall commercial credit. ${ }^{2}$

(ii) Access to public deposits. All NBFCs are classified into a small group of deposit-taking NBFCs-D and a larger group of non-deposit-taking NBFCs-ND. Of the total 9,462 NBFCs registered with the RBI as of 30 September 2019, only 74 were NBFCs-D.

(iii) Size. NBFCs vary greatly in size. The minimum capital requirement to start an NBFC is relatively modest at ₹20 million, unlike banks, which need a license to operate and larger initial capital (currently ₹5 billion for a universal bank). Many NBFCs are very small with a total balance sheet of less than ₹1 billion. In 2006, NBFCs were divided by the RBI into two categories based on their asset size (Neelima and Kumar 2017) and those with assets greater than ₹1 billion were classified as systemically important NBFCs-ND (NBFCs-ND-SI). This threshold was raised to ₹5 billion in 2014. All other NBFCs-ND were considered a separate group. Given their larger size, the NBFCs-ND-SI were expected to pose greater risks to the financial system and hence were subject to more strict prudential regulations compared to NBFCs-ND. As of 30 September 2019, there were 272 NBFCs-ND-SI, which are the primary focus of this paper. At the end of September 2019, NBFCs-ND-SI had total assets of ₹28 trillion, NBFCs-D ₹4.5 trillion, and HFCs ₹13.5 trillion (RBI 2019). The government owns the two largest NBFCs-ND-SI and about $40 \%$ of total assets of all NBFCs-ND-SI, and about $10 \%$ of NBFCs-D, but only $5 \%$ of HFCs.

10. The relevance of NBFCs as providers of commercial credit increased significantly in the 2010s, especially since the banking sector began experiencing acute asset quality stress after 2015. As of March 2020, the share of NBFCs and HFCs in the institutional credit (i.e., credit from banks and other financial institutions) was about 20\%, net of banks' credit to NBFCs and HFCs. The average growth rate of incremental credit flows disbursed by NBFCs was 13.5\% from FY2015 to FY2017, whereas during the same period, bank credit grew by a mere $8.5 \%$ (Figure 2). This highlights the crucial role that NBFCs have been playing in the Indian financial landscape.

11. The IL\&FS default and subsequent turbulence in the Indian credit markets in the autumn of 2018 have raised some important and fundamental questions about the role of NBFCs, their business model, and the optimal regulatory regime for them.

12. The rest of the paper is organized as follows. Section II presents a comparative study of NBFCs and commercial banks both from the perspective of their financial structures and business models as well as how they are regulated. Section III discusses the remarkable growth witnessed by the NBFC sector since 2014 and the circumstances which may have led to this phenomenon. Section IV looks at the genesis and the anatomy of the 2018 crisis episode that rocked the NBFC sector and eventually created ripple effects throughout the financial system and the larger economy. Section $V$ also touches upon a specific class of NBFCs, namely HFCs, that were particularly vulnerable in the aftermath of the crisis. Section VI introduces regulatory responses after the 2018 crisis. Section VII briefly describes the potential impact of the ongoing COVID-19 pandemic on this sector. Section VIII concludes with implications of the recent developments for the sustainability of NBFCs.

2 In October 2020, the RBI introduced a circular to define HFCs as those NBFCs with at least $60 \%$ of their total assets in the housing sector and no less than $50 \%$ of total assets directed toward housing financing for individuals. This would be applicable going forward, and hence this is not applicable to the analysis in this paper. 
Figure 2: Growth of Incremental Commercial Credit Flows from Various Sources

(\% per year)

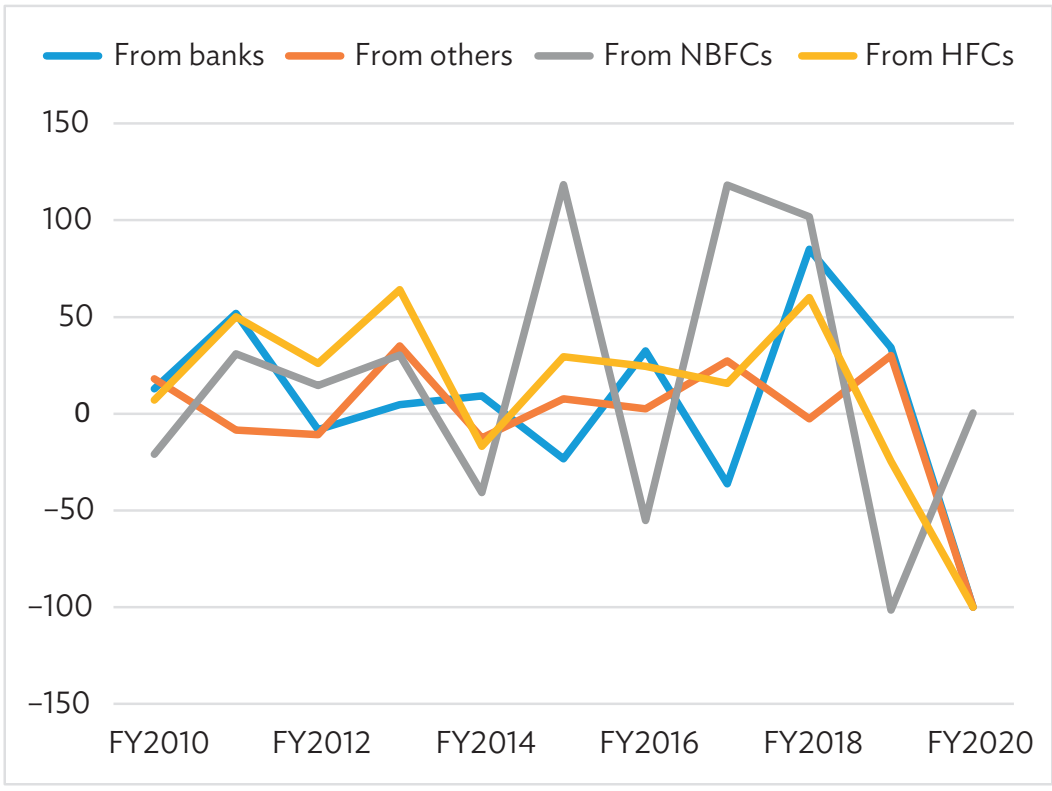

FY = fiscal year, $\mathrm{HFC}=$ housing finance company, NBFC = nonbanking financial company.

Notes:

1. Fiscal years, from 1 April of the previous year to 31 March of the year.

2. "Others" includes bond issuance to insurance companies, mutual funds, commercial paper issuance, and external commercial borrowings.

Source: Reserve Bank of India. 2020. Handbook of Statistics on the Indian Economy, 2019-20. Mumbai.

\section{COMPARISON OF NONBANKING FINANCIAL COMPANIES WITH COMMERCIAL BANKS}

13. In the model of credit where savings are intermediated through the balance sheets of financial institutions, the two most important players in India are commercial banks and NBFCs. To analyze the growth and subsequent crisis of the NBFC sector in the late 2010s, it is important to understand the differences and similarities between NBFCs and commercial banks, both with regard to their business models as well as the regulatory frameworks that they are subject to.

14. The most crucial difference in the business models of banks and NBFCs is that while banks accept public deposits, most NBFCs (i.e., NBFCs-ND) cannot. Household savings are the largest and cheapest source of funding in India. Since NBFCs cannot access household savings through deposits, their cost of funding is structurally higher than banks. Even when adjusted for the cost of maintaining reserves (the cash reserve ratio and statutory liquidity ratio), banks enjoy an advantage of 50 to 150 basis points as compared with NBFCs in pricing credit, largely because of their access to low-cost deposits. Given the relative disadvantages on the funding side, NBFCs provide credit primarily to those segments where they can compete with banks. These segments, which are inaccessible or unattractive 
for commercial banks, are where NBFCs can build specific capabilities that enable them to overcome their inherent funding cost disadvantage.

15. Banks may be constrained from serving a particular segment owing to regulatory restrictions imposed by the RBI. One such restriction relates to how much banks can lend against shares as collateral; consequently, NBFCs dominate the "loan against share" business. Some segments that operate in the informal cash economy are inaccessible to commercial banks and hence are not served by banks. A good example is small truck fleet operators whose business is primarily conducted in cash. When they need financing for new and used trucks, these operators often lack the documentation needed to obtain credit from banks. In these cases, banks' inability to underwrite loans based on informal information acts to the advantage of NBFCs. Sectors with limited access to banks also include commercial vehicles (especially used commercial vehicles), construction equipment used by small contractors, and agricultural implements. NBFCs have developed deep knowledge and skills in dealing with customers in these sectors.

16. Other segments have been unattractive to banks for reasons of high operating costs, lower credit risk appetite, or inability to assess credit risk in the absence of documented financial information of customers (as in the case of self-employed customers). The competitive dynamic segments that have a strong presence of NBFCs include the following: (i) commercial vehicle financing, including used commercial vehicles; (ii) credit against gold collateral; (iii) affordable housing loans; (v) consumer durable loans; (vi) loans against shares and margin financing for stock market traders; and (vii) loans against property for micro and small business owners as well as construction and real estate development firms.

17. NBFCs thus primarily operate in niche segments where they can overcome their funding cost disadvantage and serve a useful purpose through other capabilities such as more efficient sourcing of customers, prompt provision of services, specialized sector expertise, and better underwriting. They tend not to compete head-on with banks for similar customers. In that sense, NBFCs not only complement but also act as substitutes for banks by widening the ambit of and access to financial services.

18. However, given their exposure to niche segments, NBFCs are also characterized by concentration of risks. The dominant presence of NBFCs in these segments implies that any disruption to the NBFC model can create credit shortages in these segments, which impacts the commercial viability of these enterprises. Any disruption in the businesses of the target customer segments would imply a spike in defaults for NBFCs that lend to these segments.

19. Furthermore, in absence of direct access to household savings and any kind of retail or consumer funding, NBFCs have relied on funding from banks and bond and commercial paper markets. This has been inherently problematic because the Indian wholesale credit market itself is not deep or liquid. This means that any liquidity shock to the wholesale market would translate into a liquidity shock for the entire NBFC sector. Even if the wholesale market experiences liquidity challenges completely unrelated to the NBFC sector, funding for NBFCs would still suffer.

20. In addition to the restrictions on offering deposit products, unlike banks, NBFCs do not get access to the payments system. As a result, they cannot offer credit products that are linked to deposit accounts and payment products such as cash credit or overdraft. NBFCs primarily offer term loans which are fixed-maturity loans. Even if they provide working capital, they do so through term loans.

21. From a regulatory standpoint, NBFCs are not as tightly supervised and monitored by the RBI as banks. This is partly related to the feasibility of effectively supervising about 10,000 NBFCs as opposed to 90 scheduled commercial banks, and partly because of the role played by NBFCs in the context of 
the broader credit ecosystem. The sectors NBFCs extend credit to are largely underserved by banks and hence there is a recognition of the need to give some flexibility to NBFCs through lighter regulation. However, differences in regulations for banks and NBFCs also create the possibility of regulatory arbitrage between these two models. Many privately owned banks own NBFC as subsidiaries with sizable credit books. These entities essentially provide credit to segments that their parent banks do not and hence raise questions about possible regulatory arbitrage.

22. It therefore becomes important for the $\mathrm{RBI}$, as the regulator, to strike a careful balance between (i) giving NBFCs sufficient freedom and flexibility to serve sectors where banks do not do business; and (ii) monitoring them such that systemic risk is contained and the potential arbitrage between the two models is minimized, if not eliminated. The contradiction here is that a significant amount of funding for NBFCs comes from banks, and to the extent that NBFCs are not well regulated, the banking system faces a potential risk, too.

23. There has been a focused attempt to better align the regulatory regime for NBFCs and banks to avoid any arbitrage that may exist between the two types of financial intermediaries. This has resulted in alignment of the norms on income recognition and imposition of liquidity and asset liability management-related regulations on NBFCs. The regulatory and supervisory focus is sharper than before on systemically important NBFCs given their critical role in the overall financial architecture of the economy.

\section{RISE OF NONBANKING FINANCIAL COMPANIES IN THE 2010s}

24. The banking sector in India has gone through a cycle of credit acceleration and deceleration since the early 2000s. While the period from 2003 to 2008 was characterized by a staggering increase in the growth rate of bank credit to the commercial sector, this changed in the aftermath of the global financial crisis of 2008. After 2014, balance sheet problems in both the banking sector and the private corporate sector became apparent. This triggered the introduction of the asset quality review by the $\mathrm{RBI}$, which forced the banks to recognize stressed assets on their books. The asset quality review was applicable to both private banks and PSBs. From March 2015 to March 2018, gross NPAs in the entire banking system more than doubled to reach $11.5 \%$ of total advances of the banking sector (Figure 3 ).

25. The rise in NPAs as a share of gross advances was particularly acute for PSBs, which account for $70 \%$ of the total assets of the banking system. By March 2018, 9 out of 10 stressed banks were government owned, and gross NPAs of PSBs were as high as $14.6 \%$ and net NPAs had reached about $8.5 \%$. Alongside the bank NPA problem, corporate balance sheets also showed signs of trouble. Credit Suisse reported that by early 2017 , about $40 \%$ of the corporate debt it monitored was owed by companies that had an interest coverage ratio of less than 1 , meaning they did not earn enough to pay the interest obligations on their loans. The Economic Survey 2016-17 (Government of India 2017) termed this as the twin balance sheet problem.

26. As a result of the worsening twin balance sheet problem, incremental flows of bank credit to the commercial sector started to fall dramatically, with the most drastic decline witnessed in FY2017 (Figure 4). Given the concentration of NPAs, PSBs pulled back credit the most. In terms of sector allocation, the stock of bank credit to industry was the worst affected (Figure 5). While growth of bank credit to industry fell, the banking sector increased its lending to the NBFCs, particularly after FY2015. 
Figure 3: Gross Nonperforming Assets in the Indian Banking Sector and Nonbanking Financial Companies

(\% of total advances)

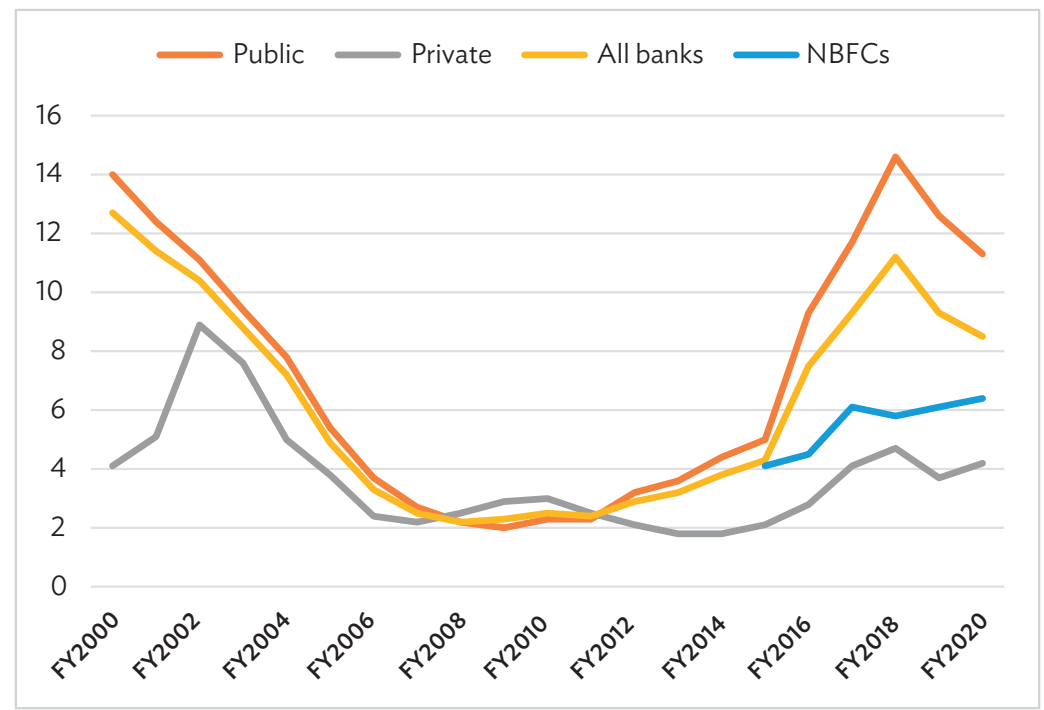

$\mathrm{FY}=$ fiscal year, NBFC = nonbanking financial company.

Note: Fiscal years, from 1 April of the previous year to 31 March of the year.

Source: Reserve Bank of India. 2020. Financial Stability Report: Issue No. 21. Mumbai (July).

Figure 4: Share of Different Types of Banks in Incremental Credit Flows (₹ trillion)

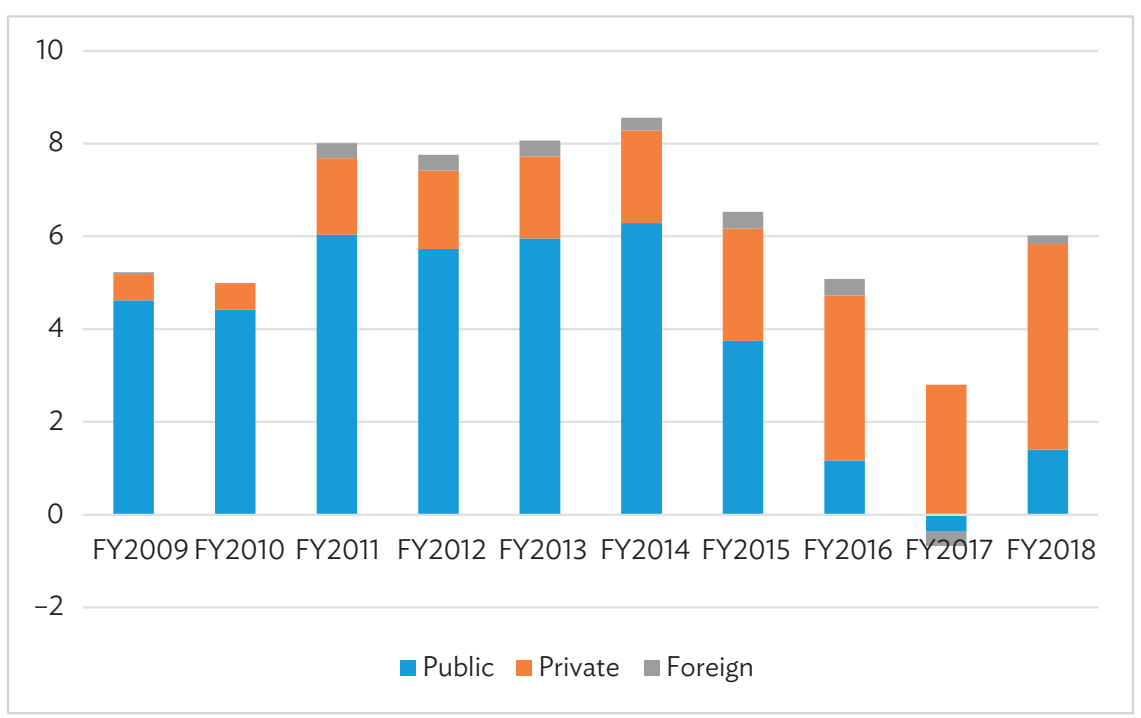

$\mathrm{FY}=$ fiscal year.

Note: Fiscal years, from 1 April of the previous year to 31 March of the year.

Source: Reserve Bank of India. 2020. Handbook of Statistics on the Indian Economy, 2019-20. Mumbai. 
From FY2015 to FY2019, banks were lending primarily to the consumer sector and NBFCs, with bank credit to these two segments growing at an average rate of about $17 \%$ while credit to industry grew at an average rate of less than $3 \%$.

Figure 5: Growth of Bank Credit across Key Sectors

(\% per year)

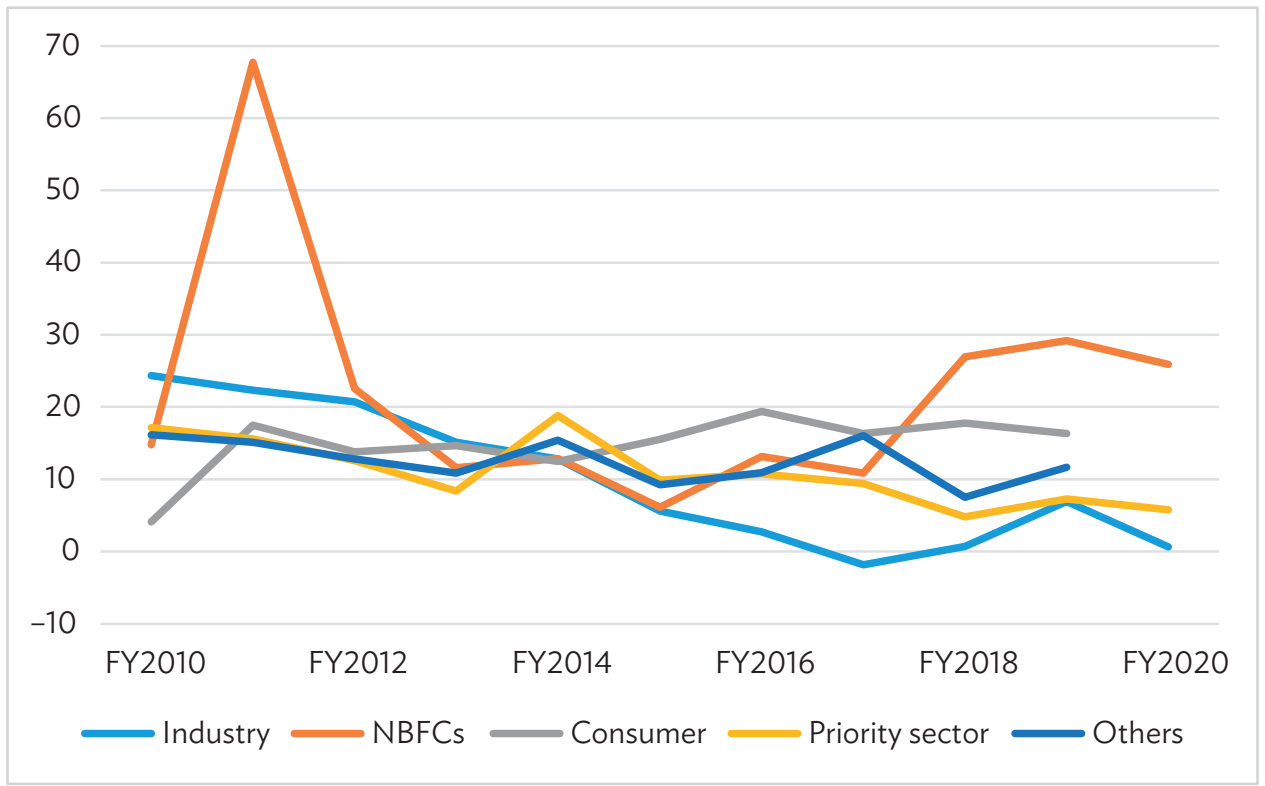

$\mathrm{FY}=$ fiscal year, $\mathrm{NBFC}=$ nonbanking financial company .

Note: Fiscal years, from 1 April of the previous year to 31 March of the year.

Source: Source: Reserve Bank of India. 2020. Handbook of Statistics on the Indian Economy, 2019-20. Mumbai.

27. From 2010, the Indian financial sector underwent a structural change. Mutual funds emerged as important players in the credit landscape. From FY2012 to FY2017 mutual funds' assets under management expanded substantially, growing at a compound annual growth rate (CAGR) of $22.1 \%$ (Figure 6). This secular growth trend received a boost during the demonetization episode in November 2016 , when close to $86 \%$ of the cash in the economy was declared illegal overnight by the government. Households and businesses rushed to deposit their cash holdings in banks, thereby resulting in a steep increase in bank deposits for FY2017. Some of these deposits were invested in mutual funds, especially debt funds, which showed a significant increase in assets under management in FY2017.

28. In addition to liquidity moving to the banking system and mutual funds, policy interest rates in India were being steadily reduced by the RBI after 2014. Interest rates had peaked in 2013 when the RBI raised its policy rate to defend the Indian rupee in response to the steep currency depreciation triggered by the "taper tantrum" episode in May 2013. By November 2017, the yield on 10-year government securities had fallen to $6.25 \%$ from $8.85 \%$ in March 2014. The combined effect of low interest rates and ample liquidity brought down the funding cost of NBFCs sharply.

29. The confluence of all these episodes indicated that on the credit supply side there was a vacuum created by the balance sheet crisis of the banks, especially the PSBs, and on the demand side falling interest rates encouraged borrowing. The situation was ripe for a dramatic growth of NBFCs, especially those larger, systematically important ones (NBFCs-ND-SI). 
Figure 6: Assets under Management by Mutual Funds

(₹ trillion)

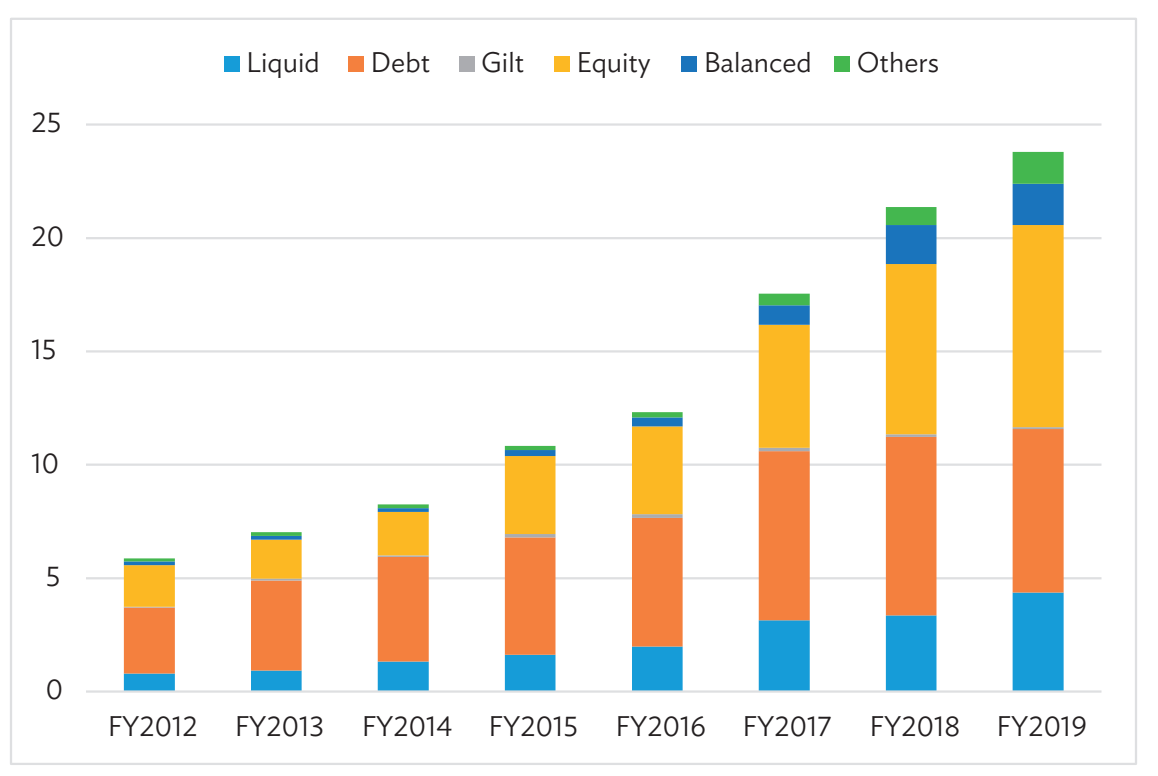

FY = fiscal year.

Note: Fiscal years, from 1 April of the previous year to 31 March of the year.

Source: Securities and Exchange Board of India.

30. The total consolidated balance sheet of these NBFCs grew at a CAGR of $11.4 \%$ from FY2013 to FY2017 and at a staggering 22\% from FY2017 to FY2019. ${ }^{3}$ Loans and advances grew at a CAGR of 13.1\% during FY2013-FY2017 and 23.4\% from FY2017 to FY2019. Several new NBFCs were also set up in the second half of the 2010s, backed by private equity.

31. There have also been changes in sectors to which NBFCs provided credit (Figure 7). From FY2016 to FY2019, industrial customers accounted for about 55\%-60\% of the total NBFC lending. There was a substantial increase of credit to commercial real estate and consumers (such as loans for buying items like white goods and cars). Growth in infrastructure credit by NBFCs from FY2015 to FY2017 was higher than that by the banking sector, which reported a contraction in lending to infrastructure. ${ }^{4}$ More than $15 \%$ of the NBFC lending was to other NBFCs. This represents larger, more established NBFCs with better credit ratings lending to newer and smaller NBFCs.

32. The funding sources of NBFCs have evolved in the 2010s (Figure 8). The primary source of capital for NBFCs since 2013 has been the wholesale credit market, with its share rising from 51.4\% in FY2013 to 58.5\% in FY2018. Market-based borrowing (i.e., issuing bonds, debentures, and short-term commercial papers) has become more important. NBFCs are inherently vulnerable to shocks given their overreliance on wholesale funding (Ghosh, Gonzalez del Mazo, and Ötker-Robe 2012). Indeed, this specific component of NBFCs' borrowing was hit the hardest when the 2018 crisis unfolded, which is discussed in detail in the next section. The secondary source of capital for NBFCs is commercial banks (Acharya, Khandwala, and Sabri Öncü 2013), with the share of borrowing from banks having risen marginally from 9.0\% in FY2013 to 12.6\% in FY2018.

3 The impact of the IL\&FS crisis was felt only in the first half of FY2020, as discussed in section I.

4 RBI. 2017. Annual Report, 2016-17. Mumbai. 
Figure 7: Sector Deployment of Nonbanking Financial Company Credit

(₹ trillion)

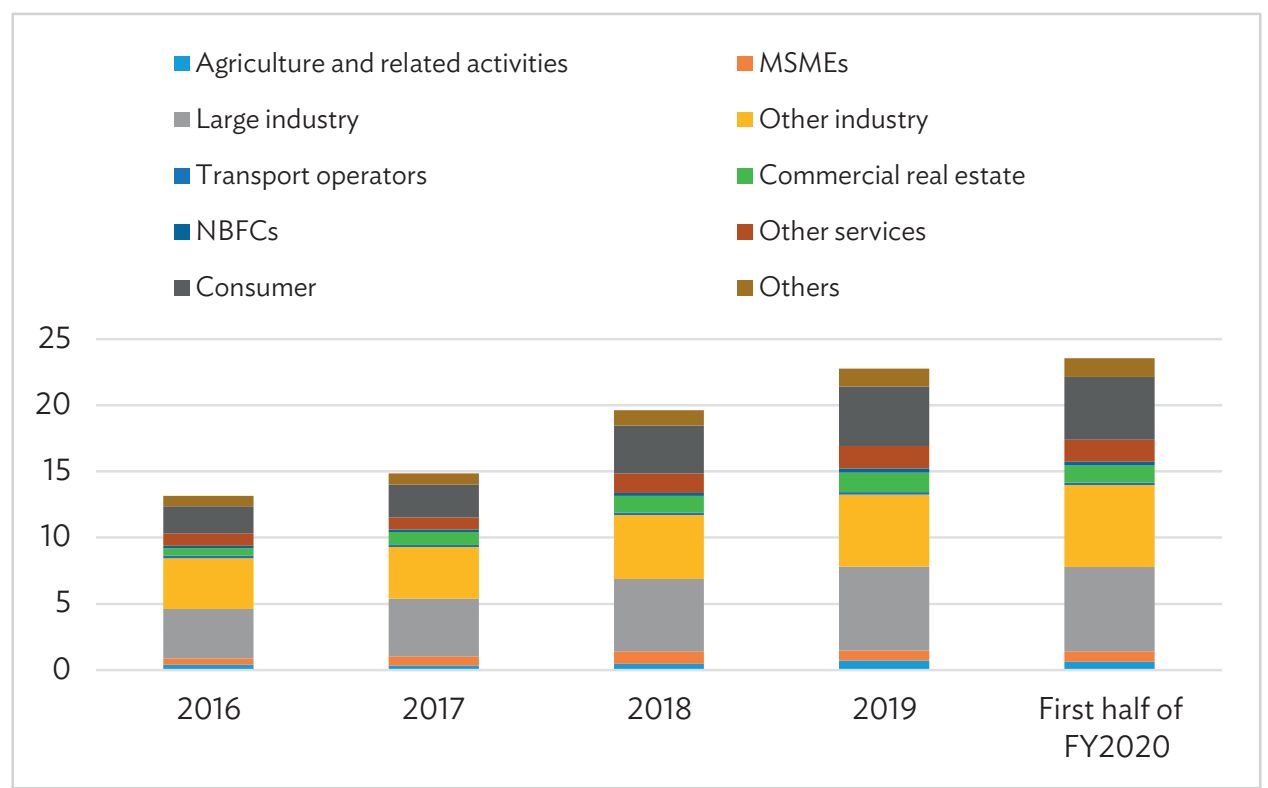

$\mathrm{FY}=$ fiscal year; $\mathrm{MSME}$ = micro, small, and medium-sized enterprise; NBFC = nonbanking financial company. Note: Fiscal years, from 1 April of the previous year to 31 March of the year.

Source: Reserve Bank of India. 2019. Report on Trend and Progress of Banking in India, 2018-19. Mumbai.

Figure 8: Incremental Funding of Nonbanking Financial Companies

(₹ trillion)

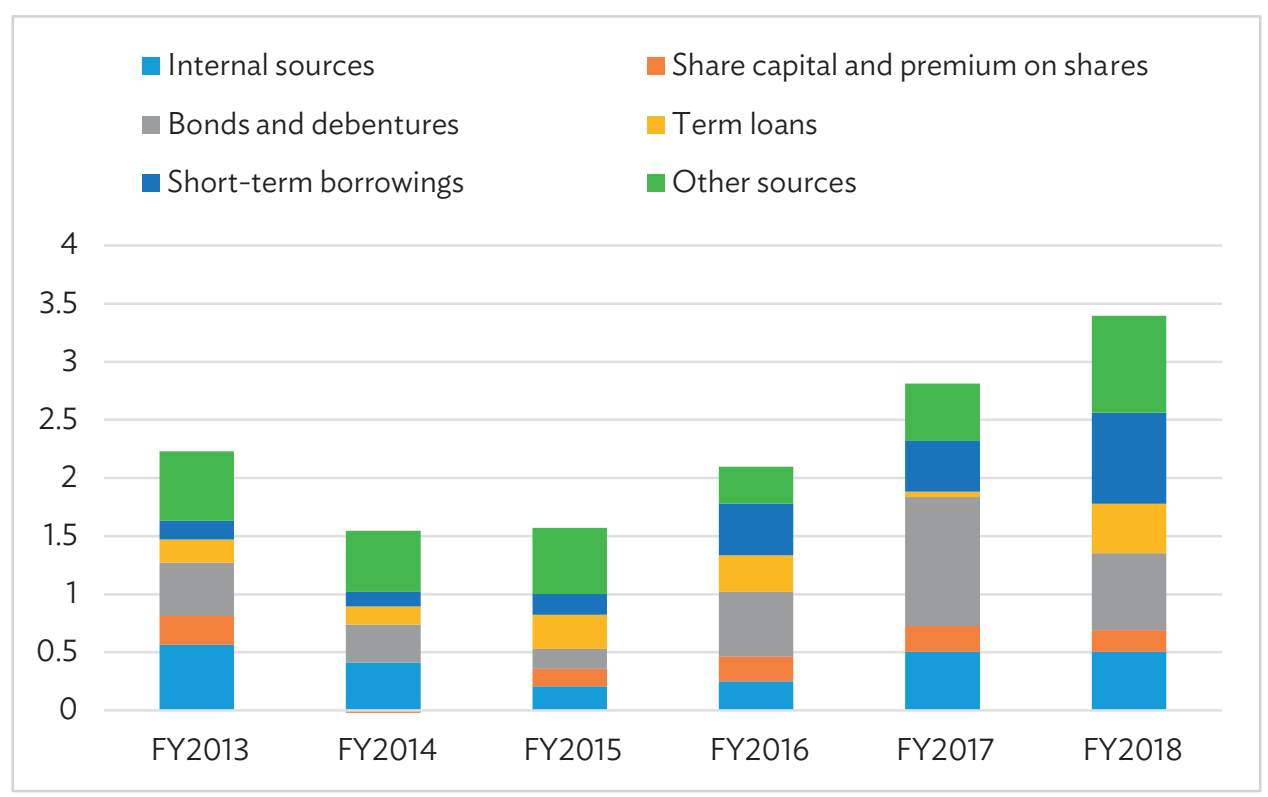

$\mathrm{FY}=$ fiscal year.

Note: Fiscal years, from 1 April of the previous year to 31 March of the year.

Source: Reserve Bank of India. 2019. Report on Trend and Progress of Banking in India, 2018-19. Mumbai. 
33. The explosive growth along with rising competition in the sector during FY2014-FY2018 masked the risks taken by NBFCs. There is evidence that NBFCs began underpricing credit. The credit premium charged by NBFCs over the risk-free yield declined during this period (Sengupta and Vardhan 2019a). Competition among NBFCs intensified with the availability of ample liquidity and significant capital infusion by private equity players, and loan pricing became competitive, especially in relatively undifferentiated business segments such as loans against property to micro, small, and medium-sized enterprises and loans to real estate developers.

34. To maintain margins during this growth phase, NBFCs reduced their costs of borrowing by shortening the maturity of their liabilities. They began borrowing short term but lending long term, which led to an asset-liability mismatch on their balance sheets. This implied that in the event of a liquidity shock when their creditors were no longer willing to roll over debt or extend new credit, they could default. Increased competition among NBFCs also resulted in some dilution of underwriting and collateral standards as the asset quality of NBFCs deteriorated steadily. Gross NPAs as a percentage of gross advances increased to 6.1\% in FY2017 from 2.9\% in FY2012 (Figure 3).

\section{GENESIS AND ANATOMY OF THE NONBANKING FINANCIAL COMPANY CRISIS OF 2018}

35. In September 2018, IL\&FS, a major infrastructure-financing NBFC, defaulted on its debt. This sent shock waves throughout the sector, resulted in a massive credit crunch, and affected the real economy as well.

36. IL\&FS is a conglomerate focused on developing and financing infrastructure projects. IL\&FS acts as the main holding company of the IL\&FS Group, with most business operations domiciled in separate companies. At the time of the default, it had 169 separate legal entities or subsidiaries in India, with complex ownership patterns. ${ }^{5}$ It is also registered as a "Core Investment Company" with the RBI, as a result of which its operations are restricted to investing in other group companies. Many of the entities were special purpose vehicles set up to own specific infrastructure assets such as roads and power generators. The group also included a large NBFC called IL\&FS Financial Services Limited, which lent to many of the special purpose vehicles of the group.

37. The overall debt of the IL\&FS entities in September 2018 was estimated to be ₹910 billion comprising bonds as well as loans from banks. IL\&FS had borrowed from the debt capital market through long-term instruments as well as short-term commercial papers. Its debt instruments were rated at the highest grade by most rating agencies. Given the large amounts involved and the high ratings, these bonds were widely held by institutions such as mutual funds, pension funds, corporate treasuries, and charitable trusts.

38. The first signs of trouble emerged in June 2018 when IL\&FS defaulted on intercorporate deposits and commercial papers worth about ₹4.5 billion. Over July and August 2018, at least two rating agencies downgraded IL\&FS's long-term ratings. On 4 September 2018, IL\&FS defaulted on a short-term loan

5 Only three of the company's subsidiaries are listed: ILFS Engineering and Construction Company, ILFS Transportation Networks, and ILFS Investment Managers. This makes it difficult to obtain detailed information on the financials of the companies. 
of ₹10 billion from the Small Industries Development Bank of India, while a subsidiary defaulted on a ₹5 billion loan owed to the same development financial institution. ${ }^{6}$

39. The IL\&FS defaults sent waves of panic through the debt capital market. In the aftermath of the defaults there was a sharp rise in credit risk premium on all bonds. All debt mutual funds became wary of taking credit risk and stopped rolling over commercial papers issued by various NBFCs. The rollover rates declined sharply from more than $95 \%$ to less than $10 \%$. The commercial paper market froze and created a severe shortage of liquidity in the debt market. New bond issuances decreased. There was even a mini-run on the mutual funds that were heavily exposed to NBFCs. Suddenly, in a span of 3 months (September to November 2018), the entire supply of funds for thousands of NBFCs dried up.

40. As the bond markets turned risk averse, NBFCs (barring a few highly rated and governmentsponsored ones) found it increasingly difficult to raise fresh debt. Credit spreads on NBFC bonds shot up and even for the best-rated NBFCs who could raise debt capital from the market, borrowing costs went up sharply in the immediate aftermath of the IL\&FS defaults (after October 2018) and remained high for most of FY2020 (Figure 9). The liquidity shock soon translated into worries about a potential solvency crisis.

\section{Figure 9: Nonbanking Financial Company and Housing Finance Company Credit Spreads} (Basis points)

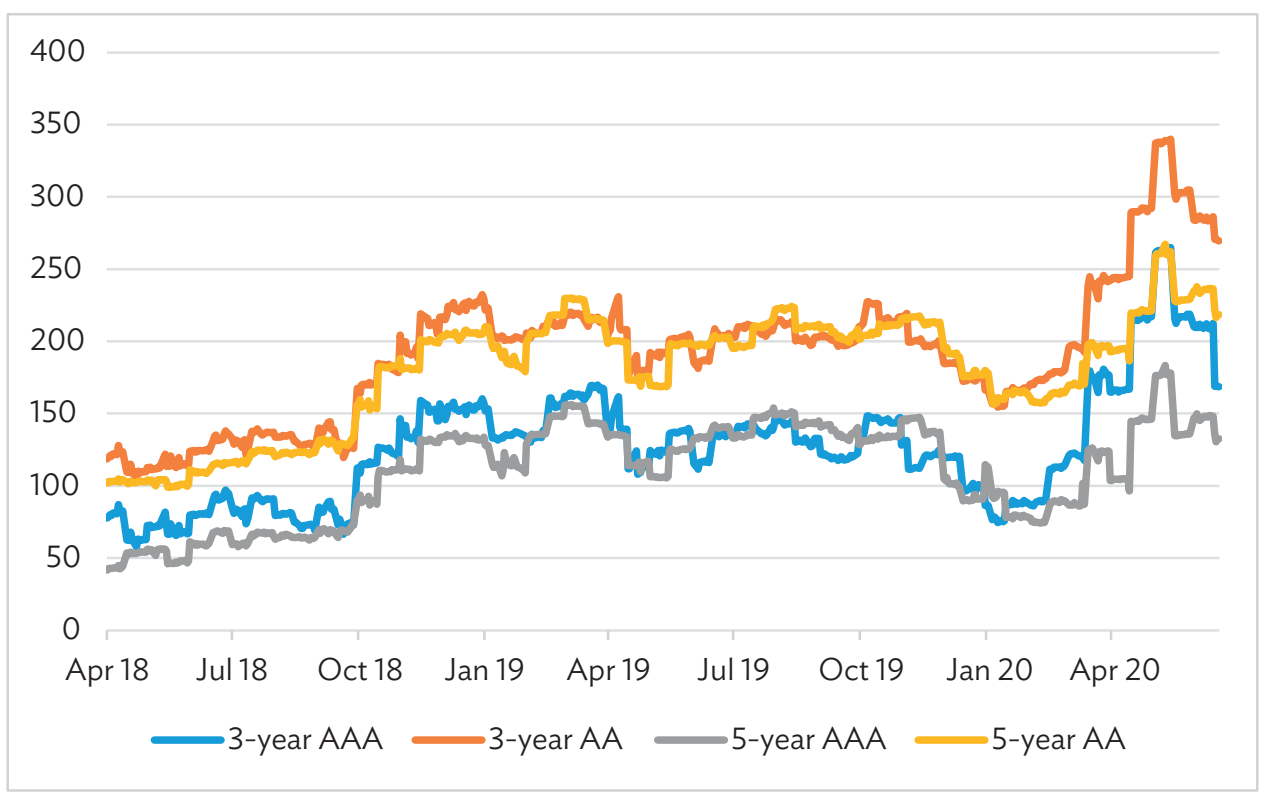

Note: The credit spread is the yield of the specific security net of the yield of the government security of the same maturity for AAA- and AA-rated bonds issued by nonbanking financial companies for 3-year and 5-year maturities.

Sources: Bloomberg; Clearing Corporation of India; and Securities and Exchange Board of India.

6 After the first default, a note issued in July 2018 by ICRA Limited (a credit rating agency) said four project special-purpose vehicles of its subsidiary IL\&FS Transportation Networks reported irregularities in debt servicing. A fifth one had to dip into its debt service reserve to pay good on dues. In August 2018, ICRA downgraded the long-term rating on ₹44.75 billion worth of debt securities from AAA to AA+ considering the "company's elevated debt levels due to the funding commitments towards Group ventures." Another statement by India Ratings and Research Private Limited said, “IL\&FS' ability to support [IL\&FS Transportation Networks'] operations has reduced significantly, given the increase in overall debt levels of the IL\&FS Group. Hence, the agency has removed the notching support for ILTN from IL\&FS.” B. Parmar. 2018. Debt and defaults: What happened to IL\&FS? moneycontrol.com. 14 September. 
41. To relieve the liquidity crunch, various RBI dispensations such as reducing the risk weights for NBFCs and encouraging banks to lend to NBFCs helped increase bank lending to NBFCs after the liquidity crunch. Figure 10 shows the public issuance of nonconvertible debentures by NBFCs and HFCs declining in the second half of FY2019 and first half of FY2020. Figure 11 shows the rise in bank lending to NBFCs during the same period.

42. To tide over the liquidity challenge, some NBFCs and HFCs resorted to selling their loan portfolios to banks. The buyers, while buying portfolios from liquidity-stressed NBFCs and/or HFCs, cherry-picked and, as a result, the residual loan books of NBFCs were perceived to be of lower credit quality. This led to a further funding squeeze, which adversely affected the ability of NBFCs to lend to the real economy. As shown in Figure 1, the impact of the IL\&FS episode was witnessed acutely in the first half of FY2020. The overall flow of credit to the commercial sector from all sources declined sharply and credit from banks and NBFCs contracted.

43. Thus, in an economy that was already experiencing a slowdown in bank credit, the NBFC crisis of 2018 aggravated the credit crunch. Sectors relying on credit flows from NBFCs suffered tremendously. Passenger car sales plummeted by one-third in a year, from a high of 244,279 cars sold in September 2018 to 162,435 in August 2019. Given the wider reach of NBFCs, this had a sharp, adverse impact on the real economy, with economic growth falling to 4.2\% in FY2020 from 6.1\% in FY2019.

Figure 10: Public Issuances of Nonconvertible Debentures by Nonbanking Financial Companies (₹ billion)

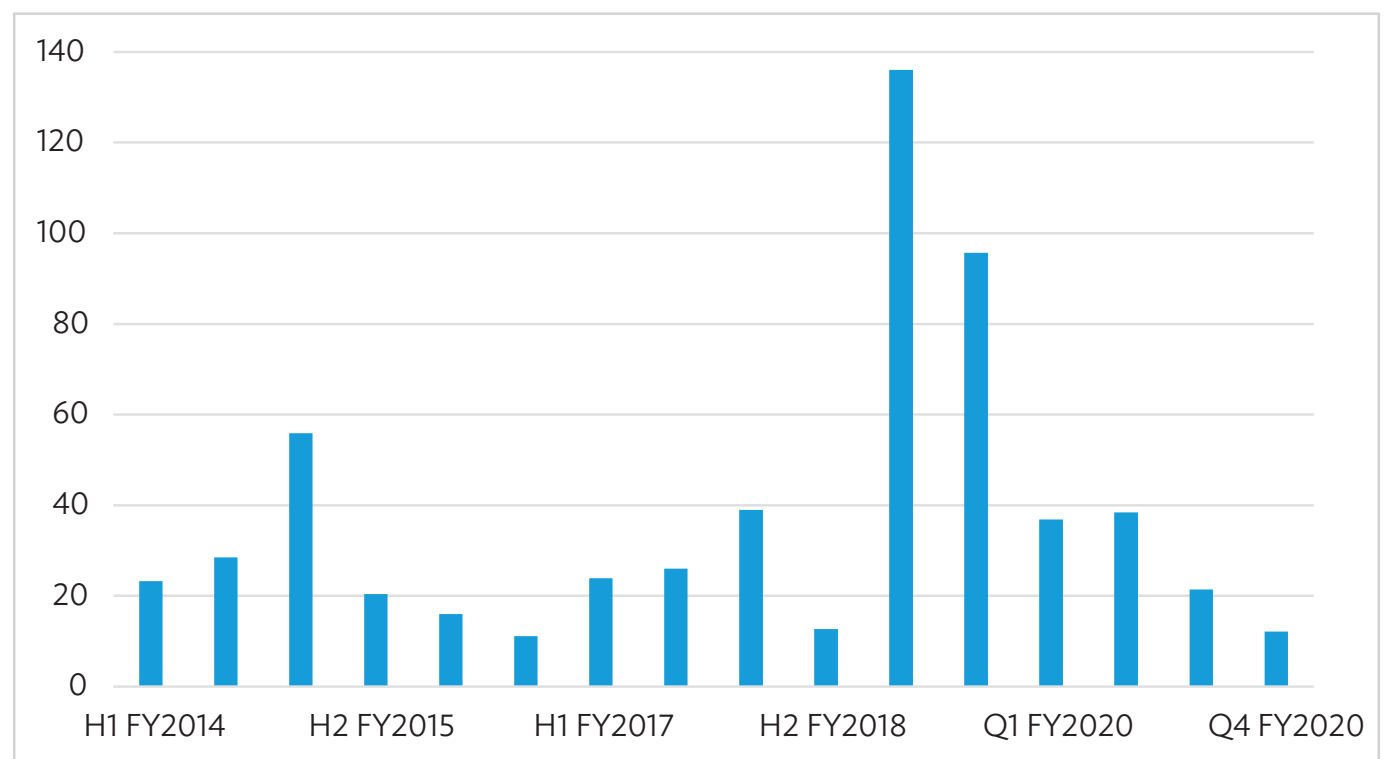

$F Y=$ fiscal year, $\mathrm{H}=$ half, $\mathrm{Q}=$ quarter.

Note: Fiscal years, from 1 April of the previous year to 31 March of the year.

Source: Kotak Institutional Equities; Prime Database. 
Figure 11: Bank Lending to Nonbanking Financial Companies and Housing Finance Companies (₹ trillion)

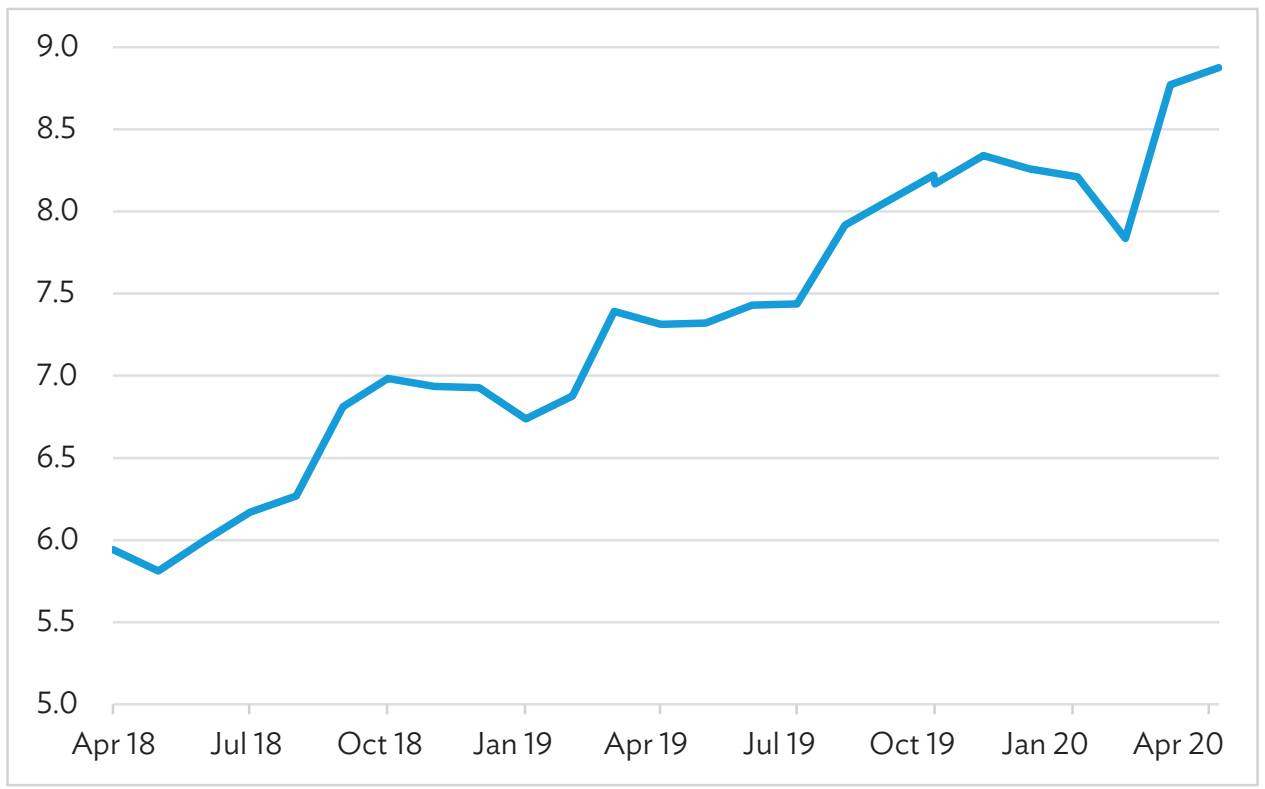

Source: Kotak Institutional Equities, Prime Database.

\section{HOUSING FINANCE COMPANIES}

44. HFCs are a specific type of NBFCs and are a significant component of the Indian financial system. HFCs started in the late 1970s with the primary purpose of extending loans to individuals for buying homes (i.e., mortgages). In the late 1980s, an apex institution, the NHB, was established and tasked with regulating and supervising HFCs. The NHB permitted the setting up of new HFCs, regulated and supervised their operations, and provided refinancing. From FY2013 to FY2018, the number of HFCs registered with the NHB increased from about 50 to close to 100. However, the top six HFCs accounted for more than $85 \%$ of all the loans from HFCs.

45. Given the close relationship of the mortgage business with real estate development, most HFCs also tend to extend loans to real estate developers, in addition to mortgages.

46. Like other NBFCs, the source of funding for HFCs is primarily bank borrowing and bonds. Prior to the IL\&FS default and the ensuing credit freeze in the markets, the larger and more established HFCs (the top six or so) had the ability to raise significant resources from the debt capital markets, while the remaining HFCs depended on the banking system.

47. Given the long maturity of their lending-most residential mortgages have a contractual maturity of 15-25 years-HFCs have a structural asset-liability mismatch problem. Their funding sources, either banks or bond markets, do not provide funding with maturity beyond 5 years. Given their acute asset-liability mismatch problem, throughout the IL\&FS episode, the HFCs were particularly adversely affected. Almost all HFCs, especially the smaller ones, faced severe liquidity challenges, 
leading them to resort to more aggressive portfolio sales to banks. In early 2019, the responsibility to regulate and supervise the HFCs was moved from the NHB to the RBI.

\section{REGULATORY RESPONSE TO THE NONBANKING FINANCIAL COMPANY CRISIS}

48. Recognizing the gravity of the challenge faced by NBFCs and HFCs following the IL\&FS crisis and the broader economic impact of this episode, the government and RBI undertook several measures to address the situation. The government's measures included

(i) the launch of a ₹1 trillion first loss default guarantee program to provide first loss protection to all NBFC lending that met the criteria of the program; and

(ii) the launch of a ₹250 billion alternative investment fund with government contribution of ₹100 billion to provide last-mile funding to stalled housing development projects; this was expected to help cash-strapped developers to complete their projects, which would help the HFCs that had given home loans to individuals buy houses in these projects.

49. The RBI took several steps to increase the flow of bank lending to NBFCs, including the following:

(i) reduction of banks' risk weights on lending to NBFCs; risk weights were made similar to those for other companies;

(ii) increase in single borrower exposure limits for NBFCs from $15 \%$ to $20 \%$ of the bank's Tier I capital; and

(iii) banks were allowed, subject to certain conditions, to lend to registered NBFCs (other than microfinance institutions) for onlending to agriculture (term loans only) up to ₹ 1 million, to micro and small enterprises up to ₹2 million, and to housing up to ₹2 million per borrower (up from ₹1 million before), and this was to be classified as priority sector lending.

50. In addition to these direct measures, several indirect measures were taken to improve liquidity for NBFCs. These indirect measures included

(i) open market operations conducted to impart liquidity of about ₹3.5 trillion to the banking system from October 2018 to March 2019;

(ii) an increase in the permissible level of the Facility to Avail Liquidity for Liquidity Coverage Ratio (FALLCR), i.e., securities that qualify for both statutory liquidity ratio and liquidity coverage ratio thus permitting banks to reduce securities held as reserves and increase their loanable funds;

(iii) changes in the securitization norms, such as a reduction of the minimum holding period requirement, to encourage NBFCs to securitize their loan books; and

(iv) transfer of the responsibility to regulate HFCs from the NHB to the RBI to harmonize regulatory oversight between banks, NBFCs, and HFCs.

51. Most of these measures were focused on improving short-term liquidity conditions for NBFCs. More structural, long-term measures included imposition of liquidity-related regulations (e.g., those related to asset liability management i.e., asset-liability mismatch) on NBFCs and moving the regulation of HFCs to the RBI from the NHB. The RBI may introduce other long-term measures, such as a stricter supervisory regime for NBFCs and HFCs, to strengthen regulation of NBFCs. 
52. As a result of these measures, bank lending to NBFCs improved during January-March 2019. Consequently, NBFC lending also picked up. However, bank lending remained skewed in favor of large and highly rated NBFCs, whereas smaller, less established, and lower-rated NBFCs continued to struggle for funding. Also, bond market liquidity for NBFCs and HFCs remained squeezed. Only highly rated (AAA) and government-sponsored NBFCs could raise capital from the bond market.

\section{IMPACT OF THE COVID-19 PANDEMIC}

53. Even as the NBFCs and HFCs were still struggling to recover from the impact of the IL\&FS crisis, the COVID-19 pandemic hit India in late January 2020. On 25 March 2020, India went into a nationwide, comprehensive lockdown, and economic activities came to an abrupt halt (Sengupta and Dev 2020). Because of the measures adopted to prevent the spread of COVID-19 (e.g., social distancing, widespread mobility restrictions, and temporary closures of all kinds of businesses), there were large-scale disruptions in supply chains and a massive reduction in both aggregate supply and demand. The strict lockdown until late June 2020 imposed enormous hardship on all economic agents (Sengupta 2020; and Sengupta and Vardhan 2020).

54. Most NBFCs had to shut down their branch networks, resulting in stalled operations. For consumer lending-focused NBFCs (such as those in the business of lending for housing, cars, and consumer durables) the underlying businesses were temporarily shut and hence there was no opportunity to lend. Almost no passenger cars were sold in India during April and May 2020, and hence there was no growth in the car loans segment.

55. Micro, small, and medium-sized enterprises are likely to have been disproportionately affected in the ongoing crisis because of their inadequate access to formal financing and lack of demand. They will struggle to stay afloat, which will affect the NBFCs who have been lending to these enterprises and lead to a buildup of asset quality stress.

56. In late March 2020, the RBI announced a 6-month moratorium on the repayment obligations for the customers of banks and NBFCs. The Supreme Court banned declarations of NPAs in September 2020 after the moratorium lapsed on 31 August, lifting the ban only in late March 2021. While official NPAs declined in December 2020, many banks reported that, without the Supreme Court suspension, NPAs would have been higher. There were no reports by NBFCs yet. With the ban lifted, NPAs are expected to spike as asset quality pressures are expected to rise, given the complete absence of revenue generation for several months. There would be a large drop in loan repayments, which would affect the profitability of NBFCs. The unsecured borrowers from the informal segment were most at risk, which was expected to especially hurt microfinance institutions among NBFCs. In general, the level of delinquencies was expected to rise significantly across all asset classes, which could force some NBFCs to deal with solvency challenges.

57. NBFCs are already facing liquidity shortages amid dwindling cash flows. This is despite policy announcements by the RBI to inject liquidity in the banking system even with the explicit objective of lending to NBFCs. Ordinarily, banks can borrow on a short-term basis from the RBI using the repo window. To supplement this facility, the RBI announced a new targeted long-term repo operations mechanism in March and April 2020 (Sengupta and Felman 2020). The RBl's long-term repo operations of ₹ 500 billion for primary and secondary market buying of NBFC bonds were targeted mostly on larger NBFCs. 
58. However, given the heightened risk aversion in the banking system, this long-term repo operations scheme has so far not been very effective in providing much-needed liquidity to NBFCs. The risk aversion in the bond market is reflected in the high credit spreads faced even by the most highly rated NBFCs during April-May 2020. In fact, the spreads during the COVID-19 pandemic have been higher than the borrowing costs faced by NBFCs in the post-IL\&FS default period in FY2019. Mutual funds have also been reducing their exposure to NBFCs.

59. No data has come out in the public domain that can provide a sense of the extent of damage caused by the COVID-19 pandemic and lockdown on the businesses of NBFCs and HFCs (other than rising borrowing costs), but anecdotal evidence suggests that there has been a deep and widespread impact. ' There may be some consolidation in the NBFC sector whereby large, established, and better-rated NBFCs acquire the smaller ones. There may also be a rise in securitization activities and portfolio sale transactions.

60. The Atmanirbhar Bharat (Self-Reliant India) fiscal relief package announced by the Finance Minister in May 2020 to alleviate the adverse impact of the COVID-19 crisis included two liquidity schemes worth ₹750 billion for NBFCs: (i) a ₹300 billion liquidity scheme to invest in investment grade debt papers; and (ii) a ₹450 billion partial credit guarantee scheme. This policy initiative eased the liquidity position of NBFCs.

\section{FUTURE OF NONBANKING FINANCIAL COMPANIES}

61. The recent crisis in the NBFC sector and resultant credit crunch in the economy raises several questions about the NBFCs' business model and in fact their very existence and importance. What are the merits of letting these specialized financial institutions function despite their obvious funding disadvantages, as opposed to encouraging banks to serve the same segments? Banks have a funding cost advantage given that they can directly access household savings, so maybe some banks will start extending their businesses to the sectors that have been exclusively served by NBFCs.

62. If banks are not able to cover all the customer segments, then what is the correct nonbank funding model? In an economy where the bond market is illiquid and underdeveloped, if access to household savings is the most sustainable form of funding, then how can nonbanks develop? The majority of NBFC funding comes from banks, which implies they still access deposits. In that case, should they still be subject to "light-touch" regulation? Or perhaps regulation could be light on the asset side but not on the liability side. The RBI, as the regulator, needs to recalibrate its approach toward NBFCs based on lessons from the IL\&FS crisis.

63. For systematically important NBFCs, the regulatory oversight, exercised through supervision, must be made more comprehensive and stringent. Systematically important NBFCs should be subject to extensive annual inspections as well as occasional regulatory actions such as the asset quality review that was done for commercial banks in response to significantly rising NPAs during FY2014 to FY2016.

\footnotetext{
Some example can be found in the following newspaper reports: V. Rawat. 2020. COVID-19 impact on NBFCs: Delayed EMI payments may increase NPA levels. ETCFO (from The Economic Times). 26 March; S. Shukia. 2020. COVID-19 Outbreak. NBFCs Face Twin Challenges of Debt Repayment, Cash Shortage. The Economic Times. 8 April; and The Hindu Business Line. 2020. COVID-19 to Impact Collections, Fresh Loan Disbursement of NBFCs in Near Term. CRISIL. 31 March.
} 
Among these systematically important NBFCs, it is necessary to identify those with significant linkages and possibly those that are too big to fail and regulate them separately and differently. It has been argued that converting these highly connected NBFCs into commercial banks or scaling down their network externalities would make the financial system sound (Rao 2020). Yet these highly connected NBFCs may be more efficient than other NBFCs in channeling funds to sectors that banks do not provide credit to. It is necessary to strike a balance between regulation and economic efficiency.

64. Related to the regulatory oversight point, there is also a need to develop a mechanism to help NBFCs deal with episodic liquidity shocks. Unlike banks, which have access to the repo operations conducted by the RBI, NBFCs have no institutionalized mechanism that allows them short-term access to liquidity. As a result, in the event of a liquidity shock to the system, NBFCs are faced with a severe credit crunch (as was witnessed in the aftermath of the IL\&FS crisis in 2018). NBFCs are essentially wholesale funded and hence are vulnerable to liquidity shocks when the wholesale markets freeze. Persistent liquidity squeeze could result in solvency problems for otherwise solvent NBFCs. In addition, most NBFCs do not own high-quality debt securities (such as government bonds) that can be offered as collateral, and hence it is not easy to replicate the bank-type repo operation for NBFCs. There may have to be a joint effort on the part of NBFCs and the regulator to create an institutionalized mechanism to provide liquidity in the event of a systemic liquidity shock.

65. Structural diversification of funding sources is also critical for the long-term survival of the NBFC model. Currently, banks and the domestic debt capital market are the only source of liabilities for NBFCs. In the domestic capital markets, mutual funds, and, to a lesser extent, insurance companies are the largest investors in debt securities of NBFCs. To create a sustainable and stable funding model, a wider pool of debt capital-both domestic and international-must be made accessible to NBFCs. Regulations related to external commercial borrowing for NBFCs may need a review. Also, regulatory changes to encourage mechanisms such as asset-backed securitization could help NBFCs access large pools of debt capital such as pension funds. Alternative investment vehicles that have higher risk appetite could be encouraged to raise capital to be invested in debt papers issued by NBFCs.

66. Other stakeholders in the financial system-credit rating agencies, auditors, the securities market regulator, banks, and mutual funds-also must learn important lessons from the 2018 crisis. One important reason that the IL\&FS default sent shockwaves through the system was the high ratings of the instruments that were defaulted upon. Therefore, improved oversight of supportive institutions such as credit rating agencies by the Securities and Exchange Board of India is also crucial. For a sustainable NBFC model to be developed, all the stakeholders must develop a nuanced understanding of the risks associated with this model. Indiscriminate supply of capital, both debt and equity, to NBFCs is likely to result in the kind of collapse that the sector recently witnessed.

67. In a developing economy like India, many customer segments remain underserved or unserved by commercial banks. As explained in section II, it may not be economically attractive for banks to serve these segments, either because they do not have the necessary expertise to serve these customers, or access to them. The raison d'être for the existence of NBFCs is to serve these customer segments that are not served well by commercial banks. Doing so requires them to have some flexibility in operations and balance sheet management compared to commercial banks. Hence, fundamentally, they need different regulatory treatment compared to commercial banks.

68. At the same time, to the extent NBFCs borrow from banks, they pose a risk to the banking system and, as they grow larger, their operations present an important systemic risk. Therefore, the regulatory approach to NBFCs must balance the need for operational and financial flexibility and containment of the systemic risk. An important step to achieving this balance is to separate NBFCs into two groups: the 
larger, systemically important ones and others. This separation would allow regulatory and supervisory attention to be focused on the systemically important entities.

69. Successful NBFCs have developed skills and expertise as well as credibility over the years. It is possible that a handful of financially strong and viable NBFCs that have the capabilities and deep specialization will survive the aftermath of the crisis and obtain greater market share, whereas a majority of the weaker ones that are undifferentiated will disappear as funding for them becomes increasingly scarce and costly. In other words, the 2018 crisis may trigger a rebalancing of the system, which could potentially be aggravated by the ongoing COVID-19 pandemic crisis.

70. NBFCs serve an important role in developing countries, such as India, where access to bank finance continues to be a challenge for a large chunk of the population and businesses. Nonbanking financial institutions, including NBFCs in India, serve market segments to which commercial banks do not offer services because of higher risk and lower returns. Because of their inherent characteristics, nonbanking financial institutions are an indispensable part of an economy's financial sector. The evolution of NBFCs in India and the 2018 crisis have provided good lessons to other developing countries. In the end, capital (both equity and debt) has to exercise the necessary discipline, and capital providers (both markets and institutions) need to become more discriminating when funding NBFCs to avoid a repeat of the 2018 crisis. 


\section{REFERENCES}

Acharya, V. V., H. Khandwala, and T. Sabri Öncü. 2013. The Growth of a Shadow Banking System in Emerging Markets: Evidence from India. Journal of International Money and Finance 39 (C). 207-230.

Ghosh, S., I. Gonzalez del Mazo, and I. Ötker-Robe. 2012. Chasing the Shadows: How Significant Is Shadow Banking in Emerging Markets? Economic Premise. 88.

Government of India, Ministry of Finance, Department of Economic Affairs, Economic Division. 2017. The Festering Twin Balance Sheet Problem. In Economic Survey 2016-17. Mumbai.

Neelima, K.M., and S. A. and Kumar. 2017. Non-Banking Financial Companies in India's Financial Landscape. RBI Bulletin. October. pp. 91-104.

Rao, M. R. 2020. NBFC Regulation-Looking ahead. Speech delivered at the National E-Summit on Non-Banking Financial Companies. 6 November.

Reserve Bank of India (RBI). 2019. Report on Trend and Progress of Banking in India, 2018-19. Mumbai.

_-_. 2020a. Financial Stability Report: Issue No. 21. Mumbai.

_- - 2020b. Handbook of Statistics on the Indian Economy, 2019-20. Mumbai.

Sengupta, R. 2020. Covid-19: Macroeconomic implications for India. Ideas for India. 24 March.

Sengupta, R., and J. Felman. 2020. RBI vs. Covid-19: Understanding the announcements of March 27. The Leap Blog. 7 April.

Sengupta, R., and H. Vardhan. 2017. Non-performing assets in Indian Banks: This time it is different. Economic \& Political Weekly. 52 (12).

- - . 2019a. Don't lgnore the Credit Risk in NBFCs. Bloomberg Quint. 25 February.

_-_. 2019b. Banking crisis impedes India's economy. East Asia Forum. 3 October.

- - 2020. The pandemic and the package. Ideas for India. 4 June.

Sengupta, R., and M. Dev. 2020. Covid-19: Impact on the Indian Economy. Indira Gandhi Institute of Development Research Working Papers. 2020 (13). 



\section{A Study of Nonbanking Financial Companies in India}

In late 2018, the default by a major nonbanking financial company (NBFC) in India led to a credit crunch in the Indian economy. This paper analyzes the evolution of the NBFC sector in India and the sector's role in extending credit, and it discusses the factors contributing to the 2018 crisis. The paper attempts to understand the advantages and disadvantages of the business model of NBFCs, and the drivers of their rapid rise and subsequent challenges. The paper also briefly discusses the potential impact of the coronavirus disease (COVID-19) pandemic on the NBFC sector.

\section{About the Asian Development Bank}

ADB is committed to achieving a prosperous, inclusive, resilient, and sustainable Asia and the Pacific, while sustaining its efforts to eradicate extreme poverty. Established in 1966, it is owned by 68 members -49 from the region. Its main instruments for helping its developing member countries are policy dialogue, loans, equity investments, guarantees, grants, and technical assistance. 